J Am Chem Soc. 2016 September 28; 138(38): 12408-12413. doi:10.1021/jacs.6b05438.

\title{
Catalysis of Heterocyclic Azadiene Cycloaddition Reactions by Solvent Hydrogen Bonding: Concise Total Synthesis of Methoxatin
}

\author{
Christopher M. Glinkerman and Dale L. Boger ${ }^{\star}$ \\ Department of Chemistry and The Skaggs Institute for Chemical Biology, The Scripps Research \\ Institute, 10550 North Torrey Pines Road, La Jolla, California 92037, United States
}

\begin{abstract}
Although examined for decades, no general approach to catalysis of the inverse electron demand Diels-Alder reactions of heterocyclic azadienes has been introduced. Typically, additives such as Lewis acids lead to non-productive consumption of the electron-rich dienophiles without productive activation of the electron-deficient heterocyclic azadienes. Herein, we report the first general method for catalysis of such cycloaddition reactions by using solvent hydrogen bonding of non-nucleophilic perfluoroalcohols, including hexafluoroisopropanol (HFIP) and trifluoroethanol (TFE), to activate the electron-deficient heterocyclic azadienes. Its use in promoting the cycloaddition of 1,2,3-triazine $\mathbf{4}$ with enamine $\mathbf{3}$ as the key step of a concise total synthesis of methoxatin is described.
\end{abstract}

\section{Graphical abstract}

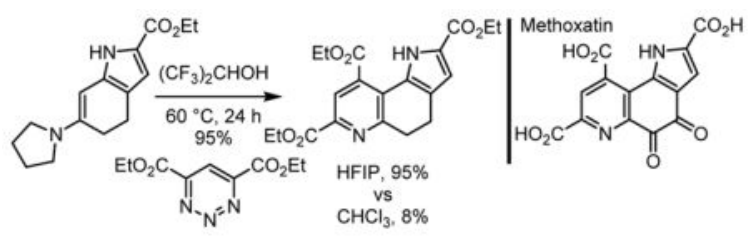

In 1964, Hauge isolated a redox active compound from the denatured glucose dehydrogenase of Bacterium anitratum (Acinetobacter caloaceticus). ${ }^{1}$ Shortly thereafter, the identical molecule was isolated from the denatured alcohol dehydrogenase of Pseudomonas sp. M27. ${ }^{2}$ It was not until 1979 that Salisbury (X-ray) elucidated the structure of the enzyme cofactor, which was named methoxatin (Figure 1). ${ }^{3}$

Methoxatin (1), also known as pyrroloquinoline quinone (PQQ), has now been isolated from a range of methylotrophic bacteria. ${ }^{4}$ This densely functionalized heterocyclic quinone serves as a cofactor for methanol dehydrogenase, which catalyzes the conversion of methanol to

*Corresponding Author: boger@ scripps.edu.

Notes

The authors declare no competing financial interest.

Supporting Information.

Full experimental details. This material is available free of charge via the internet at http://pubs.acs.org. 
formaldehyde and allows bacteria to survive on a diet of single carbon units. ${ }^{4}$ The discovery of this new cofactor in bacteria stimulated investigations aimed at identification of methoxatin-dependent mammalian enzymes. ${ }^{5}$ Because these efforts have not yet detected such an enzyme even though candidates periodically emerge, ${ }^{5}$ it remains controversial whether 1 may be a cofactor for a mammalian enzyme and constitutes a required dietary vitamin. ${ }^{5}$ Methoxatin has been shown to play a productive role in a variety of mammalian processes, including mitochondrial biogenesis ${ }^{6}$ and the attenuation of neurodegenerative diseases, ${ }^{7}$ albeit without a defined biological target that accounts for the functional activity. ${ }^{8}$ Most significant of these functional activities is its ability to reduce damage in ischemia reprofusion injury of a heart attack or stroke. ${ }^{9}$ As a result and although not presently classified as a vitamin, it is offered as a dietary supplement. ${ }^{10}$ This interest and its unusual structure has resulted in the disclosure of a series of methoxatin total syntheses that have become increasingly concise in the intervening years since its discovery. ${ }^{11}$ Herein, we report a remarkably concise total synthesis of methoxatin that emerged as a consequence of our development of the inverse electron demand Diels-Alder reactions of 1,2,3-triazines. ${ }^{12}$ Its development permits the use of a series of complementary heterocyclic azadiene cycloaddition reactions ${ }^{13}$ for the late stage divergent ${ }^{14}$ synthesis of analogues containing replacements of the fused pyridine or its substituents. Its success rested on the discovery of a powerful hydrogen bonding activation of the heterocyclic azadiene cycloaddition, and its completion resulted in the discovery of a solution to the previously unsuccessful direct single-step pyrroloquinoline oxidation to an o-quinone. ${ }^{11 \mathrm{e}}$

Thus, methoxatin (1) was envisioned to arise from a late-stage oxidation of $\mathbf{5}$ to its corresponding $o$-quinone and subsequent saponification of the resulting triester (Figure 2). The central feature of the approach is the synthesis of dihydropyrroloquinoline $\mathbf{5}$, which was envisioned to arise from the regioselective intermolecular inverse electron demand DielsAlder reaction between the enamine derived from the known ketone 2 and 1,2,3-triazine 4 . This strategy would permit a rapid synthesis of methoxatin (1) amenable to the divergent synthesis of analogues as well as provide a formidable test of the 1,2,3-triazine inverse electron demand Diels-Alder methodology.

Treatment of ketone $2^{15}$ with pyrrolidine (5.0 equiv, $4 \AA \mathrm{MS}, 0.01 \mathrm{M} \mathrm{CHCl}_{3}, 23{ }^{\circ} \mathrm{C}, 30 \mathrm{~min}$ ) provided enamine $\mathbf{3}$, which was dried in vacuo to ensure complete removal of excess pyrrolidine, and was carried forward without purification (Scheme 1). ${ }^{16}$ With enamine $\mathbf{3}$ in hand, the key intermolecular cycloaddition reaction was initially examined under conditions reported for the use of $4^{15}$ ( 2 equiv, $0.1 \mathrm{M} \mathrm{CHCl}_{3}, 60{ }^{\circ} \mathrm{C}, 5 \mathrm{~h}$ ). ${ }^{12 \mathrm{c}}$ These conditions afforded a complex mixture of products, containing a disappointing $8 \%$ yield of the desired cycloadduct 5. We initiated optimization studies, examining the reaction solvent, temperature, stoichiometry, additives, and concentration (see Supporting Information). These initial efforts established that addition of 1.5 equiv of trifluoroacetic acid (TFA, 2 equiv 4, $0.1 \mathrm{M} \mathrm{CHCl}_{3}, 23{ }^{\circ} \mathrm{C}, 5 \mathrm{~h}$ ) improved the reaction, resulting in a $34 \%$ yield of the desired cycloadduct 5 and a simplified product mixture. The success of TFA and, to a lesser extent, other haloacetic acid additives suggested that the enhanced reactivity observed may arise from aiding aromatization of the intermediate 9 by protonation of the pyrrolidine in 9 or may arise from a hydrogen bonding interaction between the haloacetic acids and 1,2,3- 
triazine 4. Unaromatized cycloadduct was not detected in the reactions and did not constitute a stalled intermediate in route to product, accounting for the low conversions. Rather, it is the [4+2] cycloaddition that was not progressing in the instances of low conversion. Thus, the additives were not simply serving as a catalyst for the final aromatization step, but were found to be accelerating the cycloaddition itself.

To probe the role of hydrogen bonding, ${ }^{17}$ further optimization of the reaction conditions was undertaken, exploring hydrogen bonding additives and solvents from which hexafluoroisoproanol (HFIP) emerged a remarkable solvent for the [4+2] cycloaddition reaction (Figure 3). Under these new found conditions, the cycloaddition of enamine 3 and 1,2,3-triazine 4 ( 2 equiv, $0.1 \mathrm{M} \mathrm{HFIP}, 60^{\circ} \mathrm{C}, 24 \mathrm{~h}$ ) proceeded cleanly to provide the desired cycloadduct 5 in a stunning $95 \%$ yield (from ketone 2). The solvents HFIP and trifluoroethanol (TFE) were uniquely successful among all solvents examined, which spanned a range of polarity, dielectric constant, and hydrogen bonding capability. This behavior arises from not only the ability of HFIP to hydrogen bond to the 1,2,3-triazine, thereby activating it for the subsequent cycloaddition, but also from its inability to serve as a nucleophile nonproductively consuming the starting 1,2,3-triazine.

To confirm hydrogen bonding of HFIP with 4, serial addition of 1,2,3-triazine 4 (0-1.5 equiv) to HFIP $\left(\mathrm{CDCl}_{3}\right)$ was examined and led to diagnostic progressive and pronounced downfield chemical shifts of the HFIP alcohol proton $(\Delta 1.36 \mathrm{ppm})$ and smaller shifts in the HFIP methine proton $(\Delta 0.19 \mathrm{ppm})$, accompanied by small shifts in the 1,2,3-triazine aryl hydrogen $(\Delta 0.03 \mathrm{ppm})$ in the ${ }^{1} \mathrm{H}$ NMR (see Supporting Information). ${ }^{19} \mathrm{~F}$ NMR analysis of the titration was also conducted and revealed no appreciable change in the chemical shifts of the HFIP fluorine signal ( $\Delta 0.09 \mathrm{ppm}$, see Supporting Information). Potentially further contributing to the overall success of the reaction, HFIP may also serve as a mild acid catalyst for promoting the final aromatization reaction involving the loss of pyrrolidine. ${ }^{18}$ Finally, the cycloaddition of $\mathbf{3}$ with 1,2,3-triazine $\mathbf{4}$ proceeds exclusively through a single mode of cycloaddition (C4/N1 vs C5/N2 1,2,3-triazine cycloaddition) and with complete regioselectivity (enamine nucleophilic carbon attached to $\mathrm{C} 4$ ). Although this is in line with expectations based on our studies with $4,{ }^{12 \mathrm{c}}$ it is notable that $\mathbf{4}$ bears two electronwithdrawing groups $\left(-\mathrm{CO}_{2} \mathrm{Et}\right)$ placed at non-complementary sites that enhance the intrinsic reactivity of the 1,2,3-triazine without altering its mode of enamine cycloaddition. ${ }^{12,19}$

In order to establish the generality of the observations, the cycloaddition of the pyrrolidine enamine derived from $\beta$-tetralone (10) with the 1,2,3-triazine $\mathbf{4}$ was studied in a more systematic manner, examining a larger range of apolar and polar aprotic solvents as well as a systematic series of protic solvents capable of varying propensities for hydrogen bonding (Figure 4). Only the cycloaddition conducted in HFIP provided the cycloadduct $\mathbf{1 1}$ effectively and it did so in excellent conversion (86\%). Similarly, the use of HFIP as an additive to the cycloaddition reaction of $\mathbf{4}$ with $\mathbf{1 0}$ conducted in $\mathrm{CHCl}_{3}$ progressively improved the conversion to $\mathbf{1 1}$ as the amount of HFIP additive was increased (Figure 4).

Additionally and just as significantly, the observations were not limited to the enamine substrates 3 and 10. The enamines 12 and 14, which react with 4 poorly, participate in much more productive cycloaddition reactions when conducted in TFE (Figure 5). With such non- 
conjugated enamines, TFE often proved to be a more effective activating solvent than HFIP since the acidity of the latter (pKa 9.3 vs 12.4) can lead to competitive non-productive consumption of the starting enamine.

Finally, a series of heterocyclic azadienes that exhibit a wide range of intrinsic reactivities was examined, comparing their behavior toward $\mathbf{1 0}$ under standard conditions to the use of HFIP as solvent (Figure 6). This included not only a series of 1,2,3-triazines 4, 16-21 that we recently introduced, ${ }^{12}$ but also the isomeric $1,3,5$-triazine $(\mathbf{2 2})^{20}$ and 1,2,4-triazine (23). ${ }^{21}$ In each case and without deliberate optimization efforts (run at 60,90 or $120{ }^{\circ} \mathrm{C}, 24$ h), the cycloadditions were more effective in HFIP, including many (e.g. 4, 20-23) that ordinarily do not productively react with $\mathbf{1 0}$ because of their modest intrinsic reactivity. Just as significantly, the regioselectivity and mode of cycloaddition were unaltered in each case examined. Thus, the use of HFIP as reaction solvent and its hydrogen bond activation extends to the larger family of heterocyclic azadienes, providing a general solution to catalyzing their inverse electron demand [4+2] cycloaddition reactions. Not surprisingly, the less reactive heterocycles 1,2-diazine (pyridazine), 1,3-diazine (pyrimidine), and 1,4-diazine (pyrazine) are unreactive toward enamine $\mathbf{1 0}$ with or without use of HFIP as solvent.

With cycloadduct 5 in hand, our focus returned to its conversion to methoxatin (1). While ostensibly straightforward on the basis of phenanthrene oxidation precedent, ${ }^{22}$ extensive efforts by Hendrickson and coworkers to affect a similar oxidation to the $o$-quinone in route to methoxatin were not successful. ${ }^{11 \mathrm{e}}$ We began with treatment of cycloadduct 5 with DDQ (4.0 equiv, $0.004 \mathrm{M} \mathrm{C}_{6} \mathrm{H}_{6}, 90{ }^{\circ} \mathrm{C}, 48 \mathrm{~h}$ ) to afford the pyrroloquinoline 6 in $90 \%$ yield (Scheme 1). At this stage, efforts were undertaken to identify conditions capable of delivering $o$-quinone 7. As reported by Hendrickson, most common oxidation methods were ineffective, either returning starting material or affecting its nonproductive consumption. ${ }^{11 \mathrm{e}}$ Although $\mathrm{OsO}_{4}$ failed to react with $\mathbf{6}$ under a variety of conditions, we found that its more reactive congener $\mathrm{RuO}_{4}$ successfully provided 7. ${ }^{23}$ Although initial efforts with $\mathrm{RuO}_{4}$ provided only small amounts of product, systematic optimization identified conditions substoichiometric in $\mathrm{Ru}\left(0.4\right.$ equiv $\mathrm{RuO}_{2}, 5.0$ equiv $\mathrm{NaIO}_{4}, 0.004 \mathrm{M} \mathrm{H}_{2} \mathrm{O} / \mathrm{CH}_{2} \mathrm{Cl}_{2} / \mathrm{CH}_{3} \mathrm{CN}$ $1: 1: 1,23{ }^{\circ} \mathrm{C}, 30 \mathrm{~min}$ ) capable of generating $\mathrm{RuO}_{4}$ in situ that provided the desired $o$-quinone 7 cleanly in $70 \%$ yield. $^{24}$

The three esters of $o$-quinone 7 were saponified according to previous reports $(0.01 \mathrm{M}$ $\mathrm{THF} / 0.5 \mathrm{M} \mathrm{LiOH}_{(\mathrm{aq})}, 23{ }^{\circ} \mathrm{C}, 6 \mathrm{~h}$ ) to provide methoxatin (1) in $94 \%$ yield as a bright red solid, which displayed spectral and physical properties in full agreement with an authentic sample. ${ }^{11}$ Because 1 bears so few ${ }^{1} \mathrm{H}$ NMR signals, synthetic methoxatin (1) was further converted in $68 \%$ yield to its acetone adduct $\mathbf{3 3}\left(0.003 \mathrm{M}\right.$ acetone/1\% $\mathrm{NH}_{4} \mathrm{OH}_{(\mathrm{aq})} 4: 1$, $23{ }^{\circ} \mathrm{C}, 30 \mathrm{~min}$ ), which also displayed spectral and physical properties in full agreement with literature reports (Scheme 2). ${ }^{11}$

As highlighted earlier, the approach was purposefully chosen to permit the divergent synthesis of methoxatin analogues by altering the selection of heterocyclic azadiene cycloaddition partner. Thus, a series of representative heterocyclic azadienes were reacted with enamine 3 in HFIP ( $24 \mathrm{~h}$ ) without optimization by simply adopting conditions identified with 10 (Figure 6) to afford the corresponding cycloadducts 33-40 (Scheme 3). 
The use of Lewis acid catalysis along with other approaches have been examined extensively for years in efforts to accelerate or promote the inverse electron demand Diels-Alder reaction of heterocyclic azadienes. ${ }^{17,25-28}$ Although there are notable successes, including Wegner's diboraanthracene ${ }^{26}$ for use with phthalazines, Rawal's Ag(I)-promoted reactions of silyloxy alkynes with phthalazines, ${ }^{27}$ and our own use of pressure-promoted reactions, ${ }^{28}$ these efforts have been largely unsuccessful in providing a general solution. Typically, additives preferentially lead to consumption of the electron-rich dienophile without productive activation of the electron-deficient heterocyclic azadienes.

Herein, we report the first general method for catalyzing such Diels-Alder reactions, enlisting the hydrogen bonding and non-nucleophilic character of perfluoroalcohols (HFIP and TFE) to selectively activate the electron-deficient heterocyclic azadienes. Its use in a concise synthesis of the bacterial enzyme cofactor methoxatin (1) from $2^{15}$ in $56 \%$ overall yield was disclosed. The route employed the key hydrogen bonding facilitated intermolecular inverse electron demand Diels-Alder reaction of the 1,2,3-triazine $\mathbf{4}$ for assembling the carbon skeleton of the natural product in a single step in superb yield (95\%, from ketone 2). The synthetic strategy outlined and the expanded heterocyclic azadiene cycloaddition scope derived from the HFIP-promoted reactions purposefully allowed for the divergent synthesis of cycloadduct analogues not easily accessible by other approaches. ${ }^{29}$

\section{Supplementary Material}

Refer to Web version on PubMed Central for supplementary material.

\section{Acknowledgments}

We gratefully acknowledge the financial support of the National Institutes of Health (CA042056, D.L.B.), the award of an NSF fellowship (NSF/DGE-1346837, C.M.G.), and the award of a Turner B. and Lesly Starr Shelton Endowment Scholarship (C.M.G.).

\section{References}

1. Hauge JG. J Biol Chem. 1964; 239:3630. [PubMed: 14257587]

2. Anthony C, Zatman L. Biochem J. 1967; 104:960. [PubMed: 6049934]

3. (a) Salisbury SA, Forrest HS, Cruse WBT, Kennard O. Nature. 1979; 280:843. [PubMed: 471057] (b) Westerling J, Frank J, Duine JA. Biochem Biophys Res Commun. 1979; 87:719. [PubMed: 222269]

4. Reviews: Duine JA, van der Meer RA, Groen BW. Annu Rev Nutr. 1990; 10:297. [PubMed: 2166547] Anthony C. Antioxid Redox Signaling. 2001; 3:757.Rucker R, Chowanadisai W, Nakano M. Altern Med Rev. 2009; 14:268. [PubMed: 19803551] Akagawa M, Nakano M, Ikemoto K. Biosci, Biotechnol, Biochem. 2016; 80:13. [PubMed: 26168402] Klinman JP, Bonnot F. Chem Rev. 2014; 114:4343. [PubMed: 24350630] Davidson VL. Adv Protein Chem. 2001; 58:95. [PubMed: 11665494] Duine JA. J Biosci Bioeng. 1999; 88:231. [PubMed: 16232604]

5. (a) Kasahara T, Kato T. Nature. 2003; 422:832. [PubMed: 12712191] (b) Felton LM, Anthony C. Nature. 2005; 433:E10. [PubMed: 15689995] (c) Rucker R, Storms D, Sheets A, Tchaparian E, Fascetti A. Nature. 2005; 433:E10. [PubMed: 15689994] (d) Kasahara T, Kato T. Nature. 2005; 433:E11.

6. (a) Chowanadisai W, Bauerly KA, Tchaparin E, Wong A, Cortopassi GA, Rucker RB. J Biol Chem. 2010; 285:142. [PubMed: 19861415] (b) Harris CB, Chowanadisai W, Mishchuk DO, Satre MA, Slupsky CM, Rucker RB. J Nutr Biochem. 2013; 24:2076. [PubMed: 24231099] (c) Bauerly KA, Storms DH, Harris CB, Hajizadeh S, Sun MY, Cheung CP, Satre MA, Fascetti AJ, Tchaparian E, 
Rucker RB. Biochim Biophys Acta. 2006; 1760:1741. [PubMed: 17029795] (d) Stites T, Storms D, Bauerly KA, Mah J, Harris C, Fascetti A, Rogers Q, Tchaparian E, Satre M, Rucker RB. J Nutr. 2006; 136:390. [PubMed: 16424117] (e) Bauerly KA, Harris C, Chowanadisai W, Graham J, Havel PJ, Tchaparian E, Satre M, Karliner JS, Rucker RB. PLoS One. 2011; 6:e21779. [PubMed: 21814553]

7. (a) Kim J, Kobayashi M, Fukuda M, Ogasawara D, Kobayashi N, Han S, Nakamura C, Inada M, Miyaura C, Ikebukuro K, Sode K. Prion. 2010; 4:26. [PubMed: 20083898] (b) Qin J, Wu M, Yu S, Gao X, Zhang J, Dong X, Ji J, Zhang Y, Zhou L, Zhang Q, Ding F. Toxicol Lett. 2015; 238:70. [PubMed: 26276080] (c) Kim J, Harada R, Kobayashi M, Kobayashi N, Sode K. Mol Neurodegener. 2010; 5:20. [PubMed: 20482893] (d) Zhang JJ, Zhang RF, Meng XK. Neurosci Lett. 2009; 464:165. [PubMed: 19699263]

8. (a) Choi O, Kim J, Kim JG, Jeong Y, Moon JS, Park CS, Hwang I. Plant Physiol. 2008; 146:657. [PubMed: 18055583] (b) Ahmed N, Shahab S. World Appl Sci J. 2010; 8:57.(c) Li L, Jiao Z, Hale L, Wu W, Guo Y. PLoS One. 2014; 9:e115010. [PubMed: 25502691] (d) Choi, O.; Hwang, I.; Kim, J.; Park, C-S. WO. 2006/075807 A1. Jan 11. 2005

9. (a) Zhu BQ, Zhou HZ, Teerlink JR, Karliner JS. Cardiovasc Drugs Ther. 2004; 18:421. [PubMed: 15770429] (b) Tao R, Karliner JS, Simonis U, Zheng J, Zhang J, Honbo N, Alano CC. Biochem Biophys Res Commun. 2007; 363:257. [PubMed: 17880922] (c) Zhu BQ, Simonis U, Cecchini G, Zhou HZ, Li L, Teerlink JR, Karliner JS. J Cardiovasc Pharmacol Ther. 2006; 11:119. [PubMed: 16891289] (d) Jensen FE, Gardner GJ, Williams AP, Gallop PM, Aizenman E, Rosenberg PA. Neuroscience. 1994; 62:399. [PubMed: 7830887] (e) Zhang Y, Feustel PJ, Kimelberg HK. Brain Res. 2006; 1094:200. [PubMed: 16709402]

10. Nakano M, Yamamoto T, Okamura H, Tsuda A, Kowatari Y. Funct Foods Health Dis. 2012; 2:307.. (b) Dietary supplements available from the following manufacturers: Swanson, Doctor's Best, Life Extension, NOW Foods, Jarrow Formulas, Source Naturals, Douglas Labs, Solaray, Pure Encapsulations, Kirkman, and Quality of Life.

11. (a) Corey EJ, Tramontano A. J Am Chem Soc. 1981; 103:5599.(b) Gainor JA, Weinreb SM. J Org Chem. 1981; 46:4317.(c) Gainor JA, Weinreb SM. J Org Chem. 1982; 47:2833.(d) Hendrickson JB, deVries JG. J Org Chem. 1982; 47:1148.(e) Hendrickson JB, deVries JG. J Org Chem. 1985; 50:1688.(f) Büchi G, Botkin JH, Lee GCM, Yakushijin K. J Am Chem Soc. 1985; 107:5555.(g) MacKenzie AR, Moody CJ, Rees CW. Tetrahedron. 1986; 42:3259.(h) MacKenzie AR, Moody CJ, Rees CW. J Chem Soc, Chem Commun. 1983:1372.(i) Jongejan JA, Bezemer RP, Duine JA. Tetrahedron Lett. 1988; 29:3709.(j) Martin P, Steiner E, Auer K, Winkler T. Helv Chim Acta. 1993; 76:1667.(k) Kemph, VJ.; Gopal, D.; Stalzer, W. WO. 2006/1042 A1. Sep 28. 2006 (l) Puthiaparampil, TT.; Sambasivam, G.; Govinda, RG.; Koramangala, RC. WO. 2014/0364613 A1. Dec 11. 2014

12. (a) Anderson ED, Boger DL. Org Lett. 2011; 13:2492. [PubMed: 21488676] (b) Anderson ED, Boger DL. J Am Chem Soc. 2011; 133:12285. [PubMed: 21736324] (c) Anderson ED, Duerfeldt AS, Zhu K, Glinkerman CM, Boger DL. Org Lett. 2014; 16:5084. [PubMed: 25222918] (d) Duerfeldt AS, Boger DL. J Am Chem Soc. 2014; 136:2119. [PubMed: 24410439] (e) Lee K, Poudel Y, Glinkerman CM, Boger DL. Tetrahedron. 2015; 71:5897. [PubMed: 26273113] (f) Glinkerman CM, Boger DL. Org Lett. 2015; 17:4002. [PubMed: 26172042]

13. (a) Boger DL. Chem Rev. 1986; 86:781.(b) Boger DL. Tetrahedron. 1983; 39:2869.

14. Boger DL, Brotherton CE. J Org Chem. 1984; 49:4050.

15. Compound 4 (ALD00110) is commercially available from Sigma-Aldrich. Compound $\mathbf{2}$ is available from commercially available ethyl 4-formyl-pyrrole-2-carboxylate by a known but improved route (see Supporting Information).

16. Dilute reaction conditions were necessary to prevent the cross-reaction of the nascent enamine $\mathbf{3}$ with unreacted ketone 2.

17. Blake JF, Lim D, Jorgensen WL. J Org Chem. 1994; 59:803.Chandrasekhar J, Shariffskul S, Jorgensen WL. J Phys Chem B. 2002; 106:8078.Huang Y, Rawal VH. J Am Chem Soc. 2002; 124:9662. [PubMed: 12175197] Huang Y, Unni AK, Thadani AN, Rawal VH. Nature. 2003; 424:146. [PubMed: 12853945] Thadani AN, Stankovic AR, Rawal VH. Proc Natl Acad Sci U S A. 2004; 101:5846. [PubMed: 15069185] Unni AK, Takenaka N, Yamamoto H, Rawal VH. J Am Chem Soc. 2005; 127:1336. [PubMed: 15686341] Türkmen YE, Rawal VH. J Org Chem. 2013; 
78:8340. [PubMed: 23869597] Review: Doyle AG, Jacobsen EN. Chem Rev. 2007; 107:5713. [PubMed: 18072808]

18. (a) Boger DL, Panek JS, Meier MM. J Org Chem. 1982; 47:895.(b) Taylor EC, Macor JE. J Org Chem. 1987; 52:4280.(c) Taylor EC, Macor JE. J Org Chem. 1989; 54:1249.(d) Chenard BL, Ronau RT, Schulte GK. J Org Chem. 1988; 53:5175.(e) Raw SA, Taylor RJK. J Am Chem Soc. 2004; 126:12260. [PubMed: 15453747]

19. (a) Itoh T, Nagata K, Kaihoh T, Okada M, Kawabata C, Arai H, Ohnishi H, Yamaguchi K, Igeta H, Ohsawa A, Iitaka Y. Heterocycles. 1992; 33:631.(b) Mattner M, Neunhoeffer H. Synthesis. 2003:413.

20. Boger DL, Schumacher J, Mullican MD, Patel M, Panek JS. J Org Chem. 1982; 47:2673.

21. (a) Neunhoeffer H, Hennig H. Chem Ber. 1968; 101:3952.(b) Boger DL, Panek JS. J Org Chem. 1981; 46:2179.

22. (a) Linstead RP, Doering WE. J Am Chem Soc. 1942; 64:1991.(b) Wendland RT, LaLonde J. Org Syn. 1954; 34:76.(c) Fuson RC, Tomboulian P. J Am Chem Soc. 1957; 79:956.(d) Okamoto T, Shudo K, Miyata N, Kitahara Y, Nagata S. Chem Pharm Bull. 1978; 26:2014. [PubMed: 28855] (e) Dehmlow EV, Makrandi JK. J Chem Res, Synop. 1986; 1:32.(f) Yamazaki S. Tetrahedron Lett. 2001; 42:3355.

23. (a) Hu J, Zhang D, Harris FW. J Org Chem. 2005; 70:707. [PubMed: 15651825] (b) Carlsen PHJ, Katsuki T, Martin VS, Sharpless KB. J Org Chem. 1981; 46:3936.

24. Ceric ammonium nitrate (CAN) was also capable of generating $o$-quinone 7 , but only in low yield despite optimization efforts.

25. Blake JF, Jorgensen WL. J Am Chem Soc. 1991; 113:7430.

26. (a) Kessler SN, Wegner HA. Org Lett. 2010; 12:4062. [PubMed: 20718452] (b) Kessler SN, Neuburger M, Wegner HA. Eur J Org Chem. 2011:3238.(c) Kessler SN, Neuburger M, Wegner HA. J Am Chem Soc. 2012; 134:17885. [PubMed: 23066957] (d) Wegner HA, Kessler SN. Synlett. 2012:699.(e) Schweighauser L, Bodoky I, Kessler SN, Haussinger D, Wegner HA. Synthesis. 2012; 44:2195.

27. (a) Turkmen YE, Montavon TJ, Kozmin SA, Rawal VH. J Am Chem Soc. 2012; 134:9062. [PubMed: 22607029] (b) Sumaria CS, Turkmen YE, Rawal VH. Org Lett. 2014; 16:3236. [PubMed: 24911346]

28. Boger DL, Panek JS. J Am Chem Soc. 1985; 107:5745.

29. While this work was under review, the H-bonding activation of hypervalent iodine-initiated alkene dimerization by HFIP was disclosed. See: Colomer I, Batchelor-McAuley C, Odell B, Donohoe TJ, Compton RG. J Am Chem Soc. 2016; 138:8855. [PubMed: 27380523] 


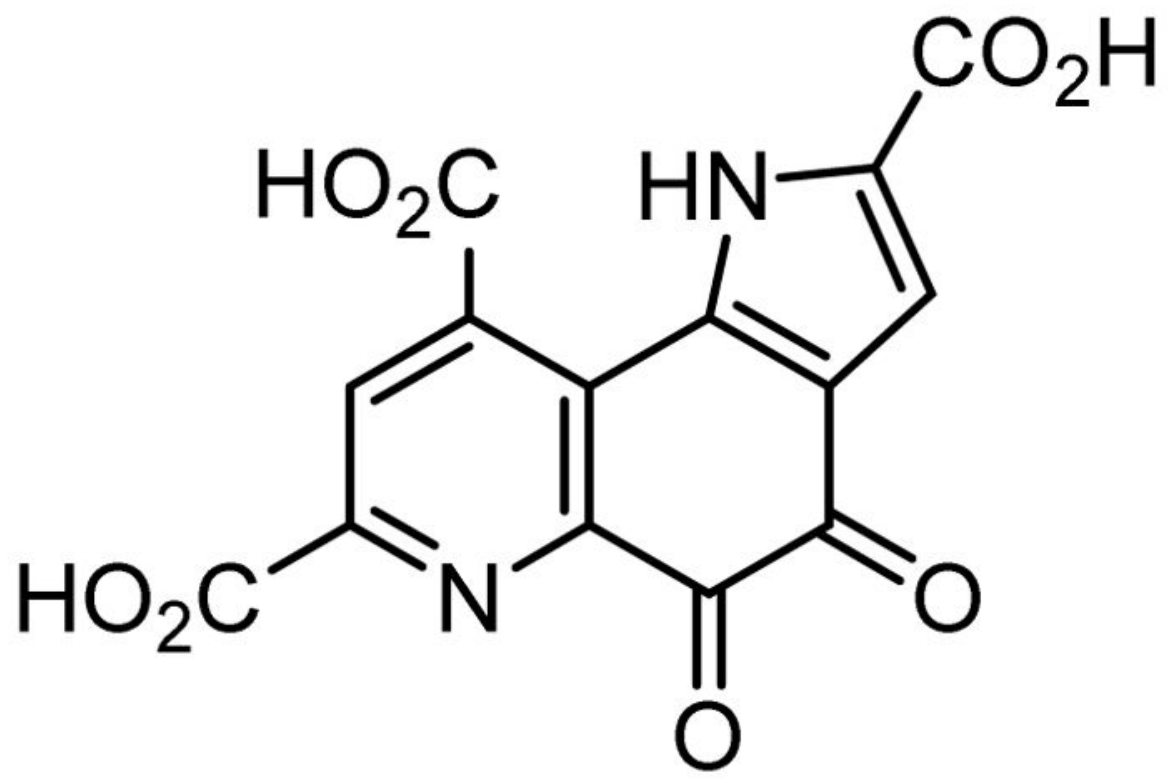

Methoxatin (1)

Figure 1.

Structure of methoxatin.

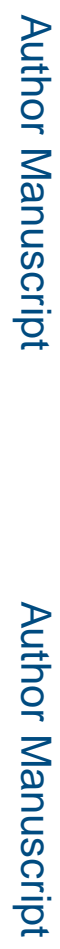


<smiles>CCOC(=O)c1cc(C)c2c(n1)CCc1cc(C(=O)OCC)[nH]c1-2</smiles>

Inverse Electron
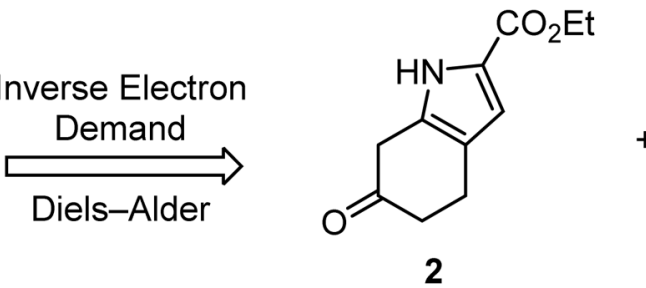<smiles>CCOC(=O)c1cc(C(=O)OCC)nnn1</smiles>

Figure 2.

Retrosynthetic analysis. 

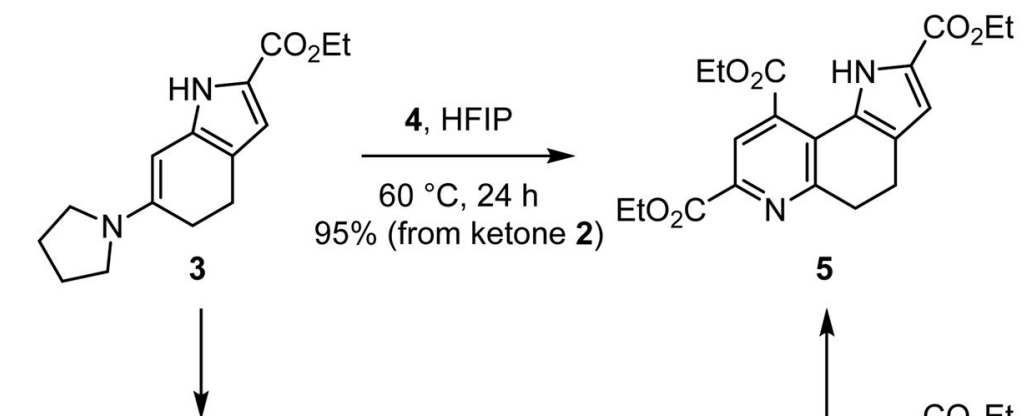

\% (from ketone 2)
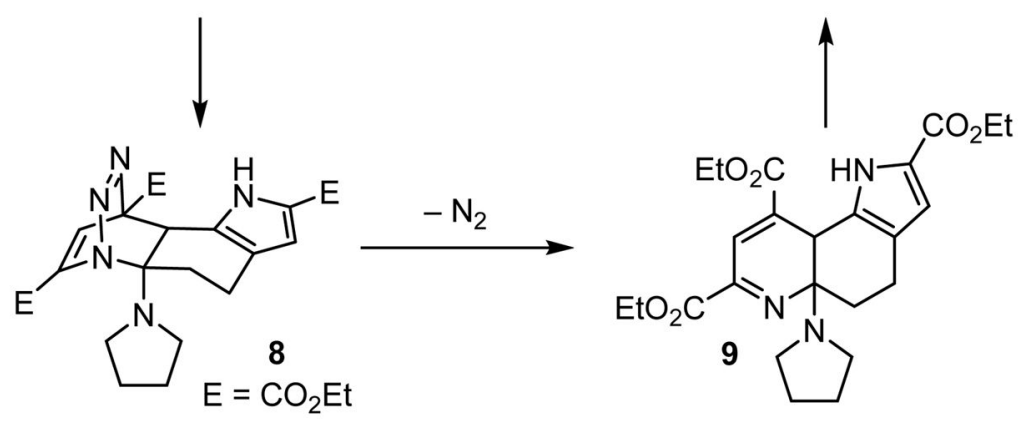

\begin{tabular}{|c|c|c|c|c|c|}
\hline entry & additive & solvent & temp $\left({ }^{\circ} \mathrm{C}\right)$ & time $(\mathrm{h})$ & yield \\
\hline 1 & none & $\mathrm{CHCl}_{3}$ & 60 & 24 & $8 \%$ \\
\hline 2 & none & $\mathrm{CH}_{3} \mathrm{CN}$ & 60 & 24 & $7 \%$ \\
\hline 3 & none & dioxane & 60 & 24 & $8 \%$ \\
\hline 4 & none & toluene & 60 & 24 & $7 \%$ \\
\hline 5 & TFA (1.5 equiv) & $\mathrm{CHCl}_{3}$ & 23 & 5 & $34 \%$ \\
\hline 6 & none & TFE & 23 & 24 & $36 \%$ \\
\hline 7 & none & HFIP & 23 & 24 & $41 \%$ \\
\hline 8 & none & HFIP & 60 & 24 & $95 \%$ \\
\hline 9 & none & $\mathrm{EtOH}$ & 60 & 24 & $0 \%$ \\
\hline 10 & none & ${ }^{i} \mathrm{PrOH}$ & 60 & 24 & $0 \%$ \\
\hline
\end{tabular}

Figure 3.

Optimization of cycloaddition reaction of enamine $\mathbf{3}$ with $\mathbf{4}$, selected results. 


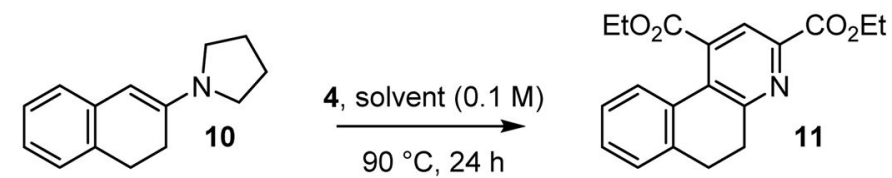

\begin{tabular}{cccc} 
entry solvent & $\begin{array}{c}\text { Non-Hydrogen } \\
\text { dielectric } \\
\text { constant* }\end{array}$ & yield \\
\cline { 2 - 3 } 1 & $\mathrm{CCl}_{4}$ & 2.24 & $10 \%$ \\
2 & $\mathrm{C}_{6} \mathrm{H}_{6}$ & 2.28 & $27 \%$ \\
3 & $\mathrm{Et}_{2} \mathrm{O}$ & 4.27 & $10 \%$ \\
4 & $\mathrm{CH}_{2} \mathrm{Cl}_{2}$ & 8.93 & $11 \%$ \\
5 & $\mathrm{THF}_{1}$ & 7.52 & $0 \%$ \\
6 & $\mathrm{CH}_{3} \mathrm{CN}$ & 36.6 & $0 \%$ \\
7 & $\mathrm{DMSO}^{2}$ & 47.2 & $4 \%$
\end{tabular}

\begin{tabular}{cccc}
\multicolumn{3}{c}{$\begin{array}{c}\text { Hydrogen } \\
\text { Bonding Solvents }\end{array}$} \\
\cline { 2 - 3 } entry solvent & $\begin{array}{c}\text { dielectric } \\
\text { constant* }\end{array}$ & yield \\
\hline 8 & $\mathrm{CHCl}_{3}$ & 4.81 & $17 \%$ \\
9 & $\mathrm{EtOH}$ & 25.3 & $0 \%$ \\
10 & ${ }^{i} \mathrm{PrOH}$ & 20.2 & $0 \%$ \\
11 & ${ }^{n} \mathrm{BuOH}$ & 17.8 & $0 \%$ \\
12 & $\mathrm{TFE}$ & 27.7 & $34 \%$ \\
13 & $\mathrm{HFIP}$ & 16.7 & $86 \%$
\end{tabular}

*from: CRC Handbook of Chemistry and Physics, 91st ed. Haynes, W. M., Ed.; CRC Press: Boca Raton, FL, 2010

\begin{tabular}{ccc} 
& \multicolumn{2}{c}{$\begin{array}{c}\text { HFIP as an } \\
\text { Additive to } \mathrm{CHCl}_{3}\end{array}$} \\
entry & equiv HFIP & yield \\
\hline 14 & 1.0 & $9 \%$ \\
15 & 5.0 & $8 \%$ \\
16 & 7.5 & $39 \%$ \\
17 & 10 & $55 \%$ \\
18 & 25 & $80 \%$ \\
19 & 50 & $82 \%$ \\
20 & 100 & $86 \%$
\end{tabular}

Figure 4.

Effect of solvent on cycloaddition. 


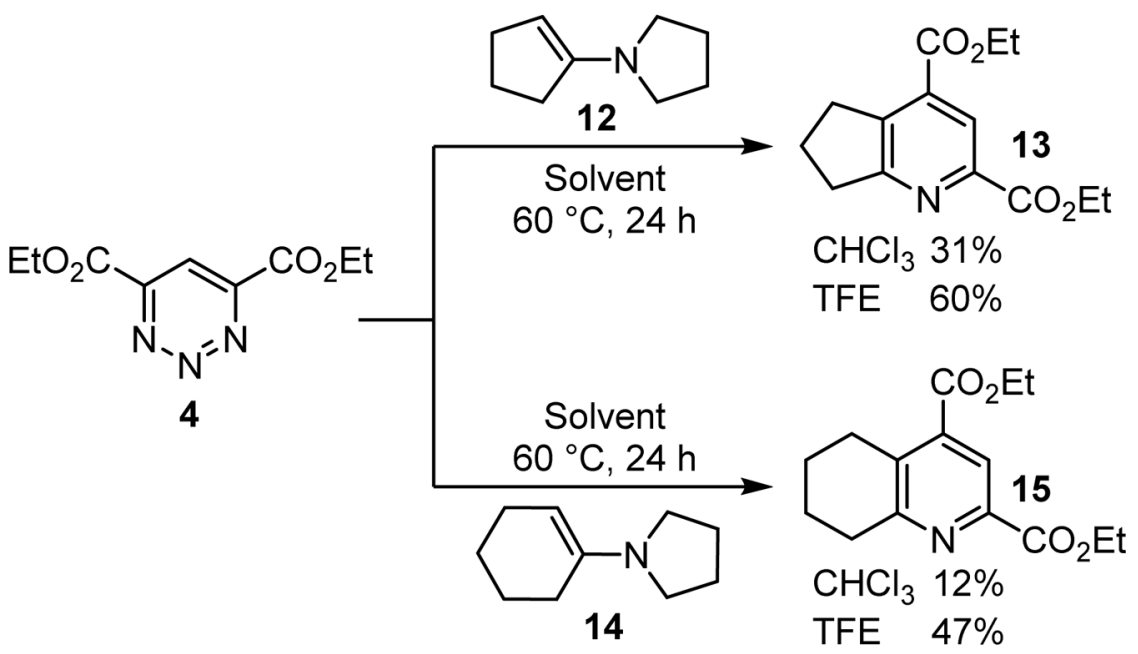

Figure 5.

Additional representative enamines. 


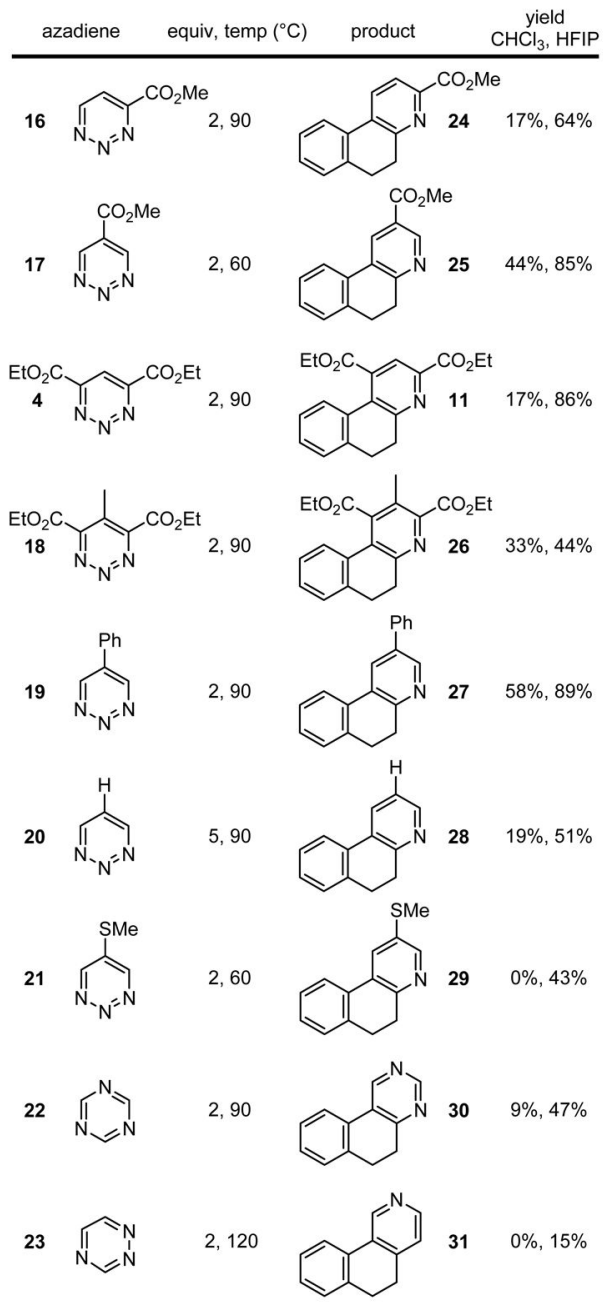

Figure 6.

Scope of heterocyclic azadienes, reaction with enamine $\mathbf{1 0}(24 \mathrm{~h})$. 

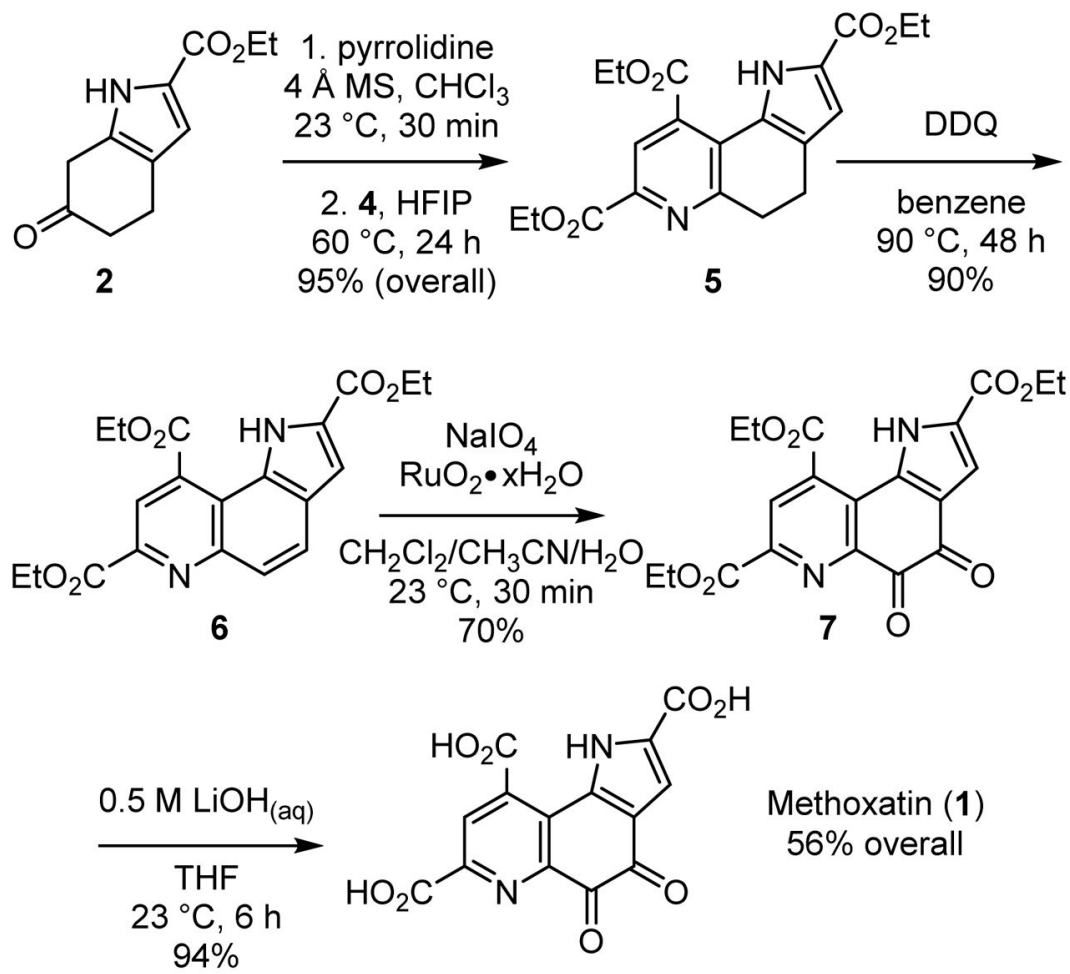

Scheme 1.

Total synthesis of methoxatin. 
<smiles>O=C(O)c1cc(C(=O)O)c2c(n1)C(=O)C(=O)c1cc(C(=O)O)[nH]c1-2</smiles>

Methoxatin (1)

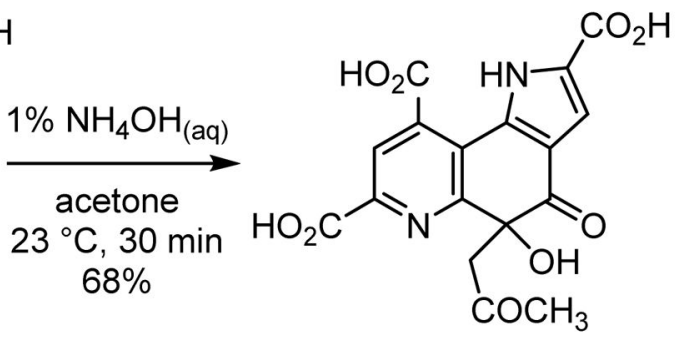

Methoxatin Acetone Adduct (32)

Scheme 2.

Synthesis of methoxatin acetone adduct. 


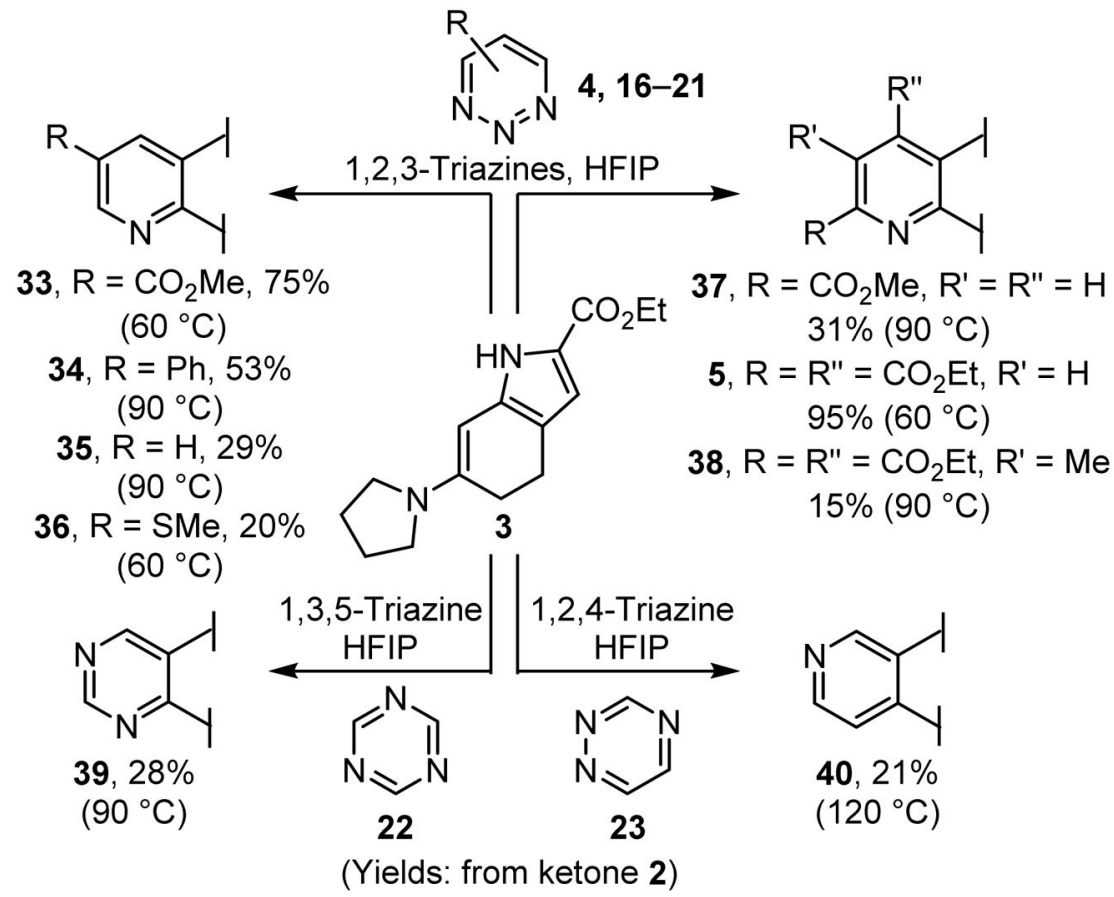

Scheme 3.

Divergent synthesis of cycloadduct analogues. 